\title{
Modeling of New Architecture of Photovoltaic Generator Based on a-Si: H/c-Si Materials
}

\author{
Talbi Mourad*, Ganouni Rached, Ezzaouia Hatem
}

Semiconductor Laboratory, Nanostructures and Advanced Technology at CRTEn, Center of Researches and Technologies of Energy of Borj Cedria, Tunis, Tunisia

Corresponding Author Email: talbi1969@yahoo.fr

https://doi.org/10.18280/ejee.210107

Received: 11 December 2018

Accepted: 2 February 2019

\section{Keywords:}

tandem solar cells, photovoltaic module, concentrator, focus, shading

\begin{abstract}
The objective of this study is to investigate the shading effect on a new architecture of Photovoltaic Generator (PVG) proposed in this work. This new architecture is constitutes of three PV modules in series connected. Two of them are constitute of amorphous silicon cells in series connected. The third Module is constitutes of monocristallin silicon cells in series connected. This architecture is conceived as a PV concentrator where the two Amorphous PV Modules are in the lower position and the third one is in the upper position (located in the Focus). The role of the upper Module consists in absorbing the solar rays reflected by the two others modules in order to gain the maximum of solar energy. This architecture aims to solve the problems existing with the architecture of tandem solar cells proposed in literature. Those problems are the mismatch between cells and the tunnel junction costs and fabrication. In this paper, we use Matlab/Simulink for modeling this architecture and studying their characteristics $(\mathrm{I}-\mathrm{V}$ and $\mathrm{P}-\mathrm{V})$ in case of partial shading. Through this study, it was found that the maximum PV power is affected by the partial shading. The findings of this research can serve as in the real construction of this new PVG architecture.
\end{abstract}

\section{INTRODUCTION}

Amorphous/crystalline silicon (a-Si:H/c-Si) hetero-junction solar cells have raised considerable interest offering a low-cost alternative to crystalline silicon solar cells with diffused pnjunctions. This silicon heterojunction (SHJ) has a high performance and potential in the research and mass production of photovoltaic devices [1]. Processing is comparatively simple and does not require high temperature steps. The high potential of this technology was recently proved by Panasonic with an independently confirmed efficiency for a laboratory cell of $24.7 \%$ [2]. The a-Si:H/c-Si solar cells consist of a thin layer of highly doped amorphous hydrogenated silicon (a$\mathrm{Si}: \mathrm{H})$, which is deposited on a moderately doped, monocrystalline silicon wafer (c-Si). The low conductivity of doped a-Si:H requires the use of a transparent, conductive layer (TCO) on top of the amorphous emitter, which minimizes resistive losses as well as reflective losses. Additionally, high efficiency features such as surface texturing, and the incorporation of a thin intrinsic a-Si:H layer have been used to enhance the efficiency [3].

Some defects of mismatch between cells and tunnel junction costs and fabrication, are existing in the architecture of tandem solar cells proposed in literature [4]. To solve these defects, this paper establishes a new architecture of a Photovoltaic Generator (PVG), constitutes of three PV modules in series connected (previously described in abstract). It is modelled using Matlab/Simulink and its model is simulated with the aim to make a theoretical study of this new architecture in order to take into a count some constraints when constructing this new architecture. These constraints are the partial shading effect of the upper PV Module on the two lower PV ones and the number of the PV cells in the upper PV one and also the surface of each of them. In fact, we have to insure a certain compromise between reducing the partial shading effect caused by the upper PV Module on the two lower PV ones and reducing the loss of sun lights reflected by those two lower PV modules. The findings shed new light on the effect of shading in the characteristics ( $\mathrm{I}-\mathrm{V}$ and $\mathrm{P}-\mathrm{V})$ of the new architecture modelled by Matlab/Simulink.

The remainder of this paper is organized as follow: in section 2 we will detail the new proposed architecture of the PV Generator (PVG). In section 3, we will deal with the effect of the partial shading. In section 4, we will detail the Matlab Simulation of the proposed PV Generator Exposed to Different Partial Shading Conditions In section 5, we will present and discuss the results obtained from Matlab/Simulink of this new architecture and this for different values of insolation. Those results will be in terms of $\mathrm{I}-\mathrm{V}$ and $\mathrm{P}-\mathrm{V}$ characteristics. Finally we will conclude in section 6 .

\section{PAGE SETUP THE NEW PROPOSED PVG ARCHITECTURE}

The most important keys to highly efficient MJ solar cells are the abilities to: First, match current of all junctions at the optimal working condition (By using tunnel junction). Second, match the lattice constant of all epitaxial layers to the substrate to achieve high crystalline quality [5]. Therefore, in this paper we propose a new model of tandem solar cell. This model (Figure 1) is an innovation in the field of photovoltaic and permits to avoid the previously mentioned problems. 


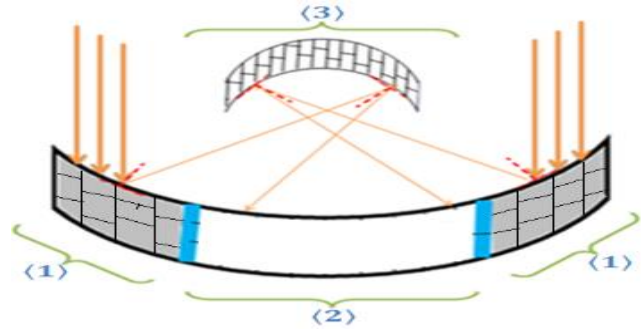

Figure 1. New model of tandem solar cells with parabolic trough concentrator [6]

This model (Figure 1) is a new parabolic trough concentrator which is constituted by a number of a-Si:H/c-Si tandem solar cells. According to this Figure, this new parabolic trough concentrator is constituted of two parabolic receivers. The first parabolic receiver is located in lower position and contains two regions numbered $\langle\mathbf{1}\rangle$ and one region numbered $\langle 2\rangle$. The latter contains series connection cells (a-Si:H single junction) in each of the two regions $\langle\mathbf{1}\rangle$. The second parabolic receiver is located in upper position and contains only one region numbered $\langle\mathbf{3}\rangle$. The latter contains series connection cells (c-Si single junction).

As previously mentioned, the model is made up of two parabolic solar cells and they absorb respectively different wavelength. Incident ray comes into the first parabolic receiver, low wavelength $(250 \mathrm{~nm} \sim 750 \mathrm{~nm})$ of solar spectrum is absorbed and the rest is reflected to be absorbed by the upper PV modules at the high wavelength $(750 \mathrm{~nm} \sim 1125 \mathrm{~nm})$.

Crystalline silicon c-Si and amorphous silicon a-Si:H solar cells have similar structure. They have absorbent layer $\mathrm{TiO}_{2}$, p-n junction and reflective layer $\mathrm{Al}_{2} \mathrm{O}_{3}$ (Figure 2: (a) a-Si:H single junction solar cells and (b) $\mathrm{c}-\mathrm{Si}$ single junction solar cells).
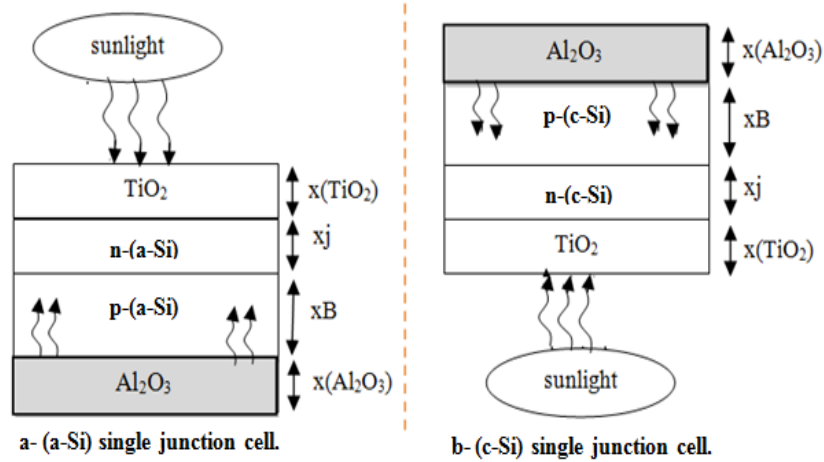

Figure 2. Composition of (a-Si) and (Si-c) solar cells [6]

Arriving on both regions $\langle\mathbf{1}\rangle$ of the first parabola the solar radiation will undergo a total reflection to arrive at the second parabola. A large part of the spectrum will be absorbed by the cell of large gap a-Si: $\mathrm{H}$, the rest is reflected from this cell to be absorbed by the cell c-Si and we win the most of energy.

\section{EFFECT OF PARTIAL SHADING}

In this new architecture, the PV Module in the upper position can be shaded and also causes the shading of the two others modules in the lower position. Consequently, we will study in section 4 the effects of this shading on the characteristics $\mathrm{I}-\mathrm{V}$ and $\mathrm{P}-\mathrm{V}$ of the overall proposed $\mathrm{PV}$ generator.

\section{SIMULATION OF THE PROPOSED PV GENERATOR EXPOSED TO DIFFERENT PARTIAL SHADING CONDITIONS}

In our Matlab Simulation and as previously mentioned, three PV Modules are used in the proposed PV Generator (Figure 3). Two PV modules are in lower position (Regions numbered 1 in Figure 1) and the third PV Module is in the upper position, precisely in the Focus region (Figure 1). All of those PV Modules are in series connected. Each of the two PV modules in the lower position is constitutes of six Amorphous PV cells in series connected. The third one is constituting of six Monocristallin PV cells in series connected. In Figure 3 is illustrated the new proposed architecture of the PV Generator.

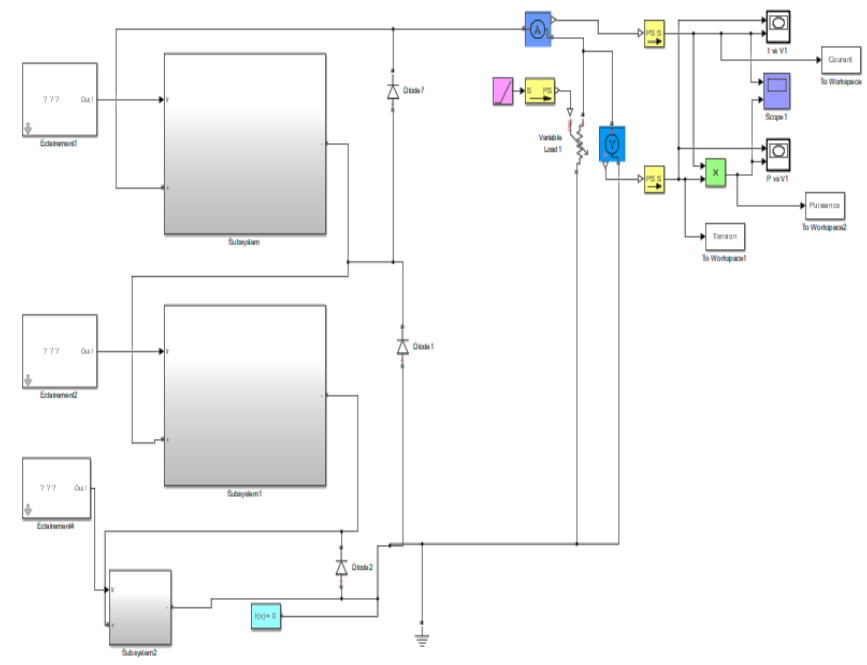

Figure 3. The overall proposed photovoltaic generator under partial shading

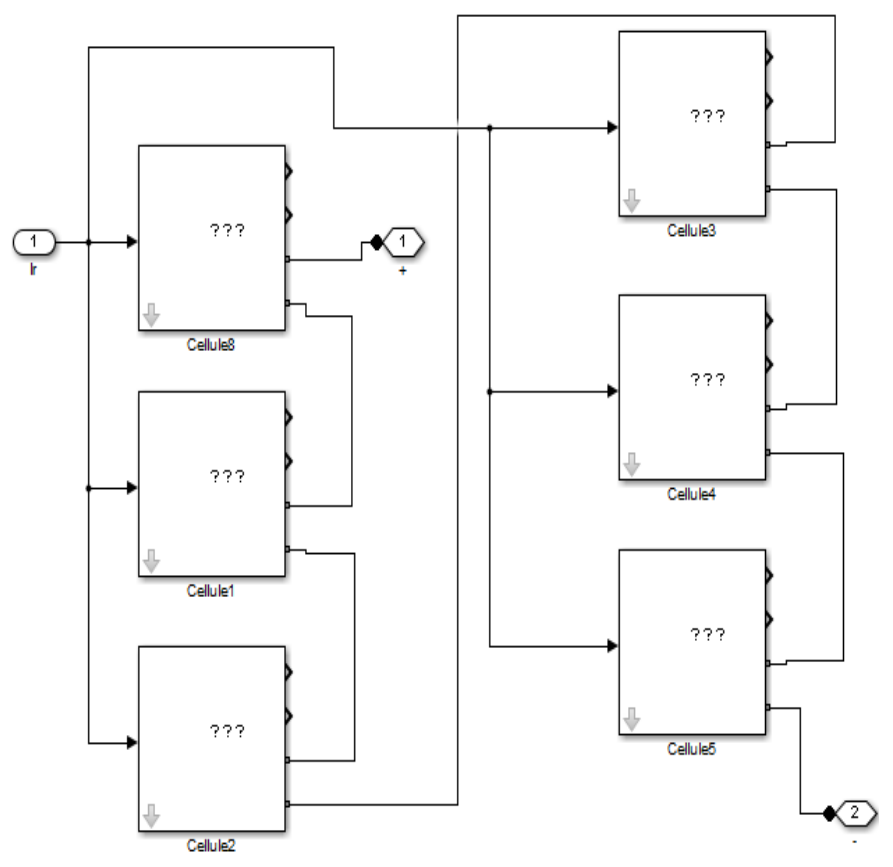

Figure 4. Inside of one PV module used in the overall proposed photovoltaic generator (Figure 3) 


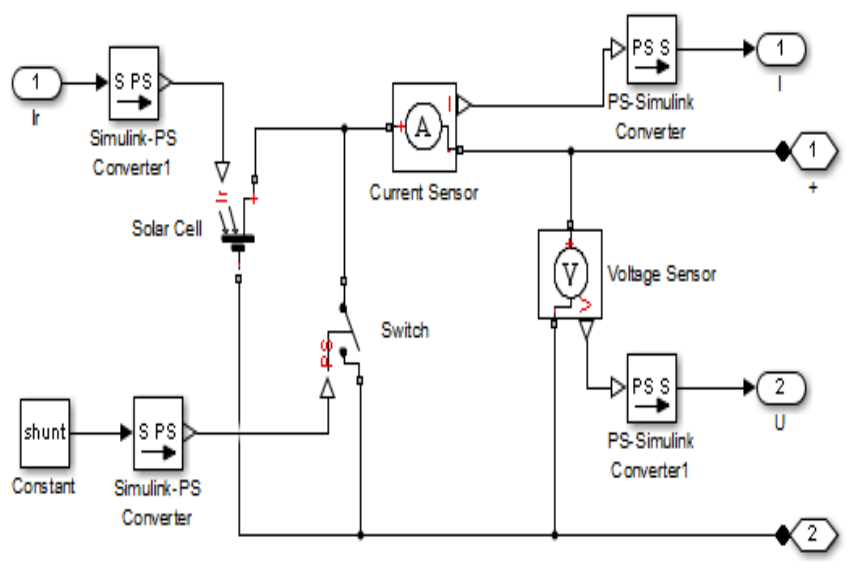

Figure 5. Inside of the block of the PV Cell Model proposed in [7] and used in the overall proposed Photovoltaic

Generator (Figure 3)

This PV Cell architecture is taken from (. The input of this PV Cell is the insolation and his outputs are the current and voltage. As previously mentioned, it can be a monocristallin or polycristallin or Amorphe PV cell.

In Figures 6 and 7 are illustrated the I-V and P-V characteristics for the three cases, monocristallin, polycristallin and amorphous.

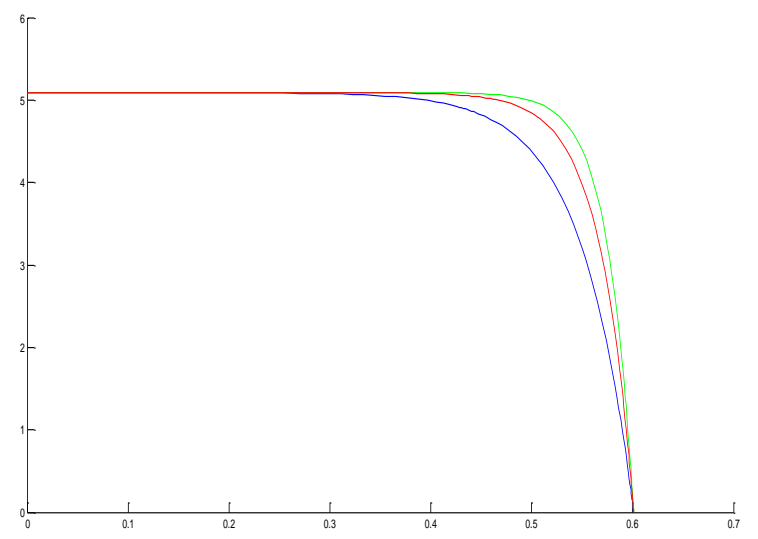

Figure 6. $I-V$ characteristics: curve in green color for monocristallin PV Cell, curve in blue color for Amorphous PV Cell, curve in red color for Polycristallin PV Cell

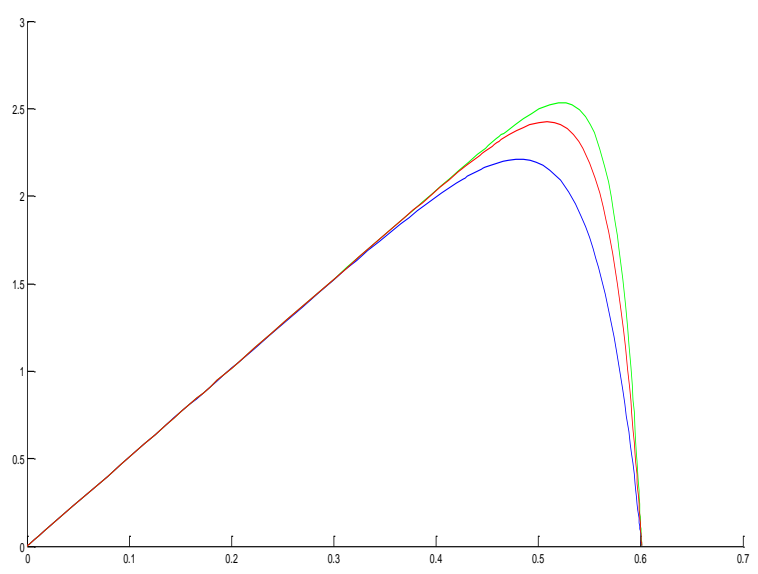

Figure 7. P-V characteristics: curve in green color for monocristallin PV Cell, curve in blue color for Amorphous PV Cell, curve in red color for Polycristallin PV Cell
In Table 1 are lised the different parameters of one PV Cell [5] used in of our model of the Generator Photovoltaic.

Table 1. Parameters of the PV Cell used in both [5] and our GPV model

\begin{tabular}{|c|c|}
\hline PV Cell parameter & Value \\
\hline $\begin{array}{l}\text { Short Circuit Current } \\
\text { (A) }\end{array}$ & 5.09 \\
\hline $\begin{array}{l}\text { Open Circuit Voltage } \\
\text { (V) }\end{array}$ & 0.601 \\
\hline Temperature $\left({ }^{\circ} \mathrm{C}\right)$ & 25 \\
\hline Irradiance $\left(\mathrm{W} / \mathrm{m}^{2}\right)$ & 1000 \\
\hline $\begin{array}{c}\text { Type of the used PV } \\
\text { Cell }\end{array}$ & $\begin{array}{l}\text { Monocristallin or Amorphous or } \\
\text { Polycristallin }\end{array}$ \\
\hline
\end{tabular}

\section{RESULTS AND DISCUSSION}

In this section we will present the results obtained from simulation of the proposed Model of the Generator Photovoltaic. Those results are different $\mathrm{I}-\mathrm{V}$ and $\mathrm{P}-\mathrm{V}$ characteristics (Figures. 8-11) for different values of insolation (with and without shading).

The obtained results show that the maximum PV power is affected by the partial shading. Three local peaks appear on the $\mathrm{I}-\mathrm{V}$ and $\mathrm{P}-\mathrm{V}$ characteristics (Figures 8-11). These peaks vary with the level of the partial shading. During partial shading, each module is exposed to different irradiances. Therefore, each panel has its own maximum (peak) power.

One solution to completely solve the problem of shading is to make this new architecture of PVG as a solar tracker.

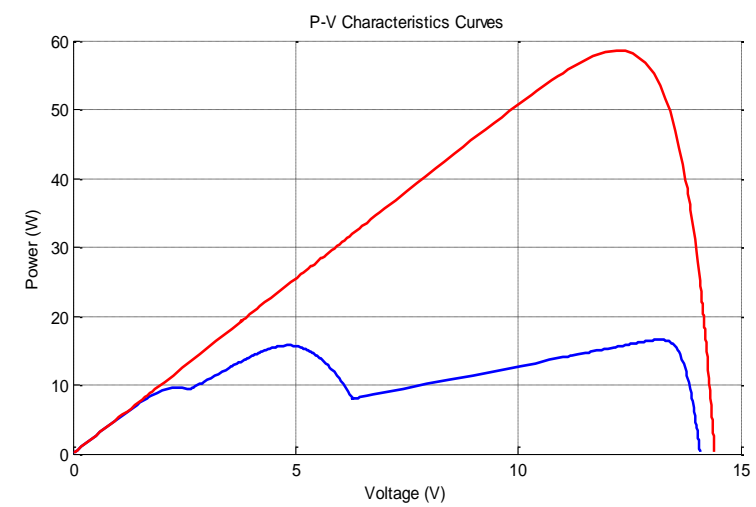

(a)

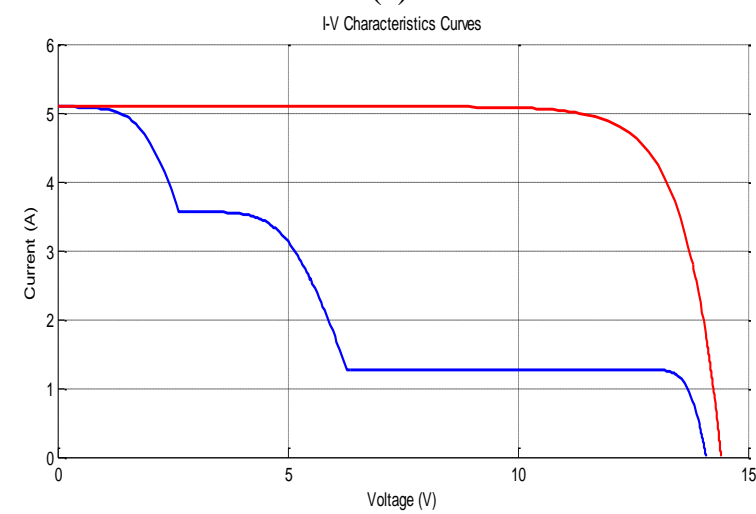

(b)

Figure 8. Characteristics $P-V(a)$ and $I-V(b)$ (Without Shading in Red color $\left([1000,1000,1000] W / m^{2}\right)$ and With Shading in Blue Color $\left.\left([1000,700,250] W / m^{2}\right)\right)$ 


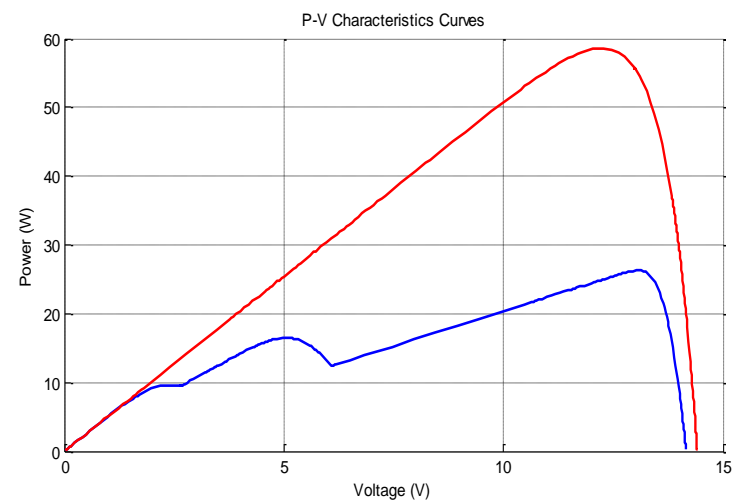

(a)

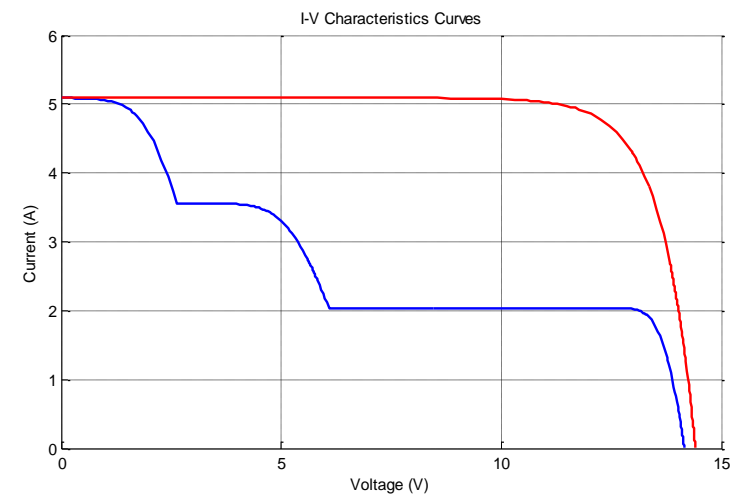

(b)

Figure 9. Characteristics $P-V(a)$ and $I-V(b)$ ( Without Shading in Red color $\left([1000,1000,1000] \mathrm{W} / \mathrm{m}^{2}\right)$ and With Shading in Blue Color $\left.\left([1000,700,400] \mathrm{W} / \mathrm{m}^{2}\right)\right)$

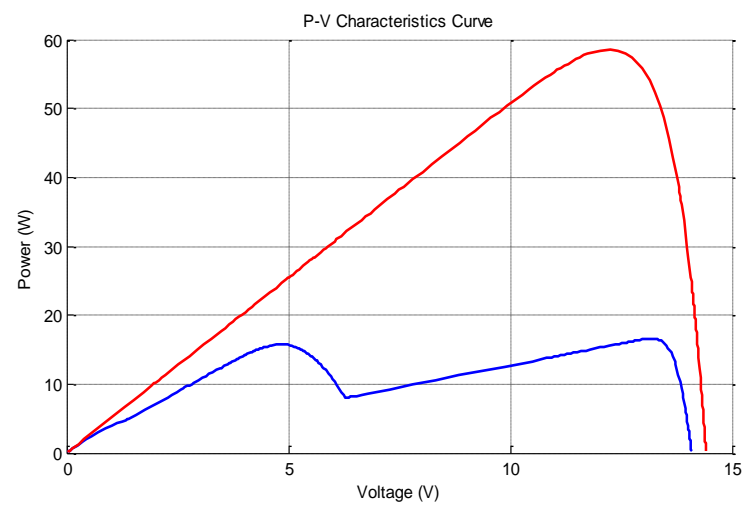

(a)

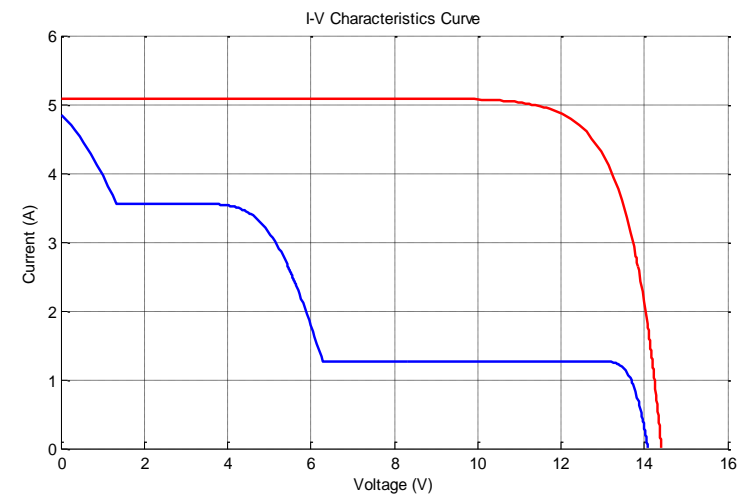

(b)

Figure 10. Characteristics $P-V(a)$ and $I-V(b)$ (Without Shading in Red color $\left([1000,1000,1000] \mathrm{W} / \mathrm{m}^{2}\right)$ and With Shading in Blue Color $\left.\left([700,1000,250] \mathrm{W} / \mathrm{m}^{2}\right)\right)$

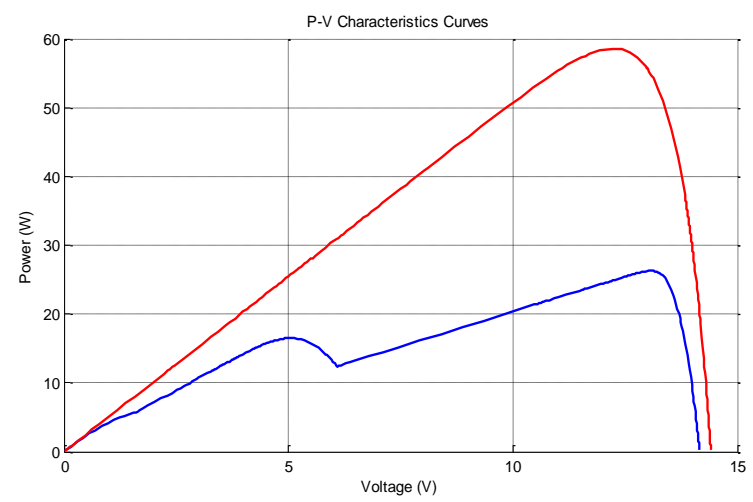

(a)

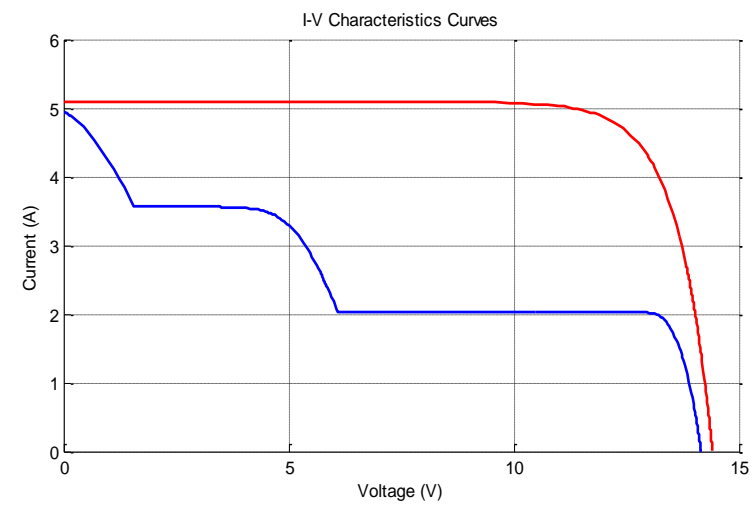

(b)

Figure 11. Characteristics $P-V(a)$ and $I-V(b)$ (Without Shading in Red color $\left([1000,1000,1000] W / \mathrm{m}^{2}\right)$ and With Shading in Blue Color $\left.\left([700,1000,400] \mathrm{W} / \mathrm{m}^{2}\right)\right)$

\section{CONCLUSION}

In this paper we propose a new architecture of a Photovoltaic Generator (PVG), constitutes of three PV modules in series connected. Two of them are constituting of amorphous silicon cells in series connected and the third one by monocristallin silicon cells. This new architecture is conceived as a PV concentrator where the two Amorphous PV Modules are in the lower position and the third one is in the upper position (in the Focus). This new architecture is proposed in order to solve problems existing in the architecture of tandem solar cells proposed in literature. Those problems are the mismatch between cells and the tunnel junction costs and fabrication. The role of the upper Module consists in absorbing the solar rays reflected by the two others modules in order to gain the maximum of solar energy. In this paper, we use Matlab/Simulink for modeling this new architecture of a Photovoltaic Generator and studying their characteristics (I $\mathrm{V}$ and $\mathrm{P}-\mathrm{V}$ ) in case of partial shading. In fact the two lower $\mathrm{PV}$ modules are partially shaded by the upper PV one.

One solution to completely solve the problem of shading is to make this new architecture of PVG as a solar tracker. In our future research work, we will do the implementation of this new architecture of PVG as a Solar Tracker. Then including this Solar Tracker in an overall grid connected Photovoltaic system including a DC-DC Converter and an MPPT Controller based on neural networks. 


\section{ACKNOWLEDGMENT}

We would like to thank all the people who contributed in some way to this work which was supported by CRTEn (Center of Researches and Technologies of Energy of Borj Cedria, Tunis and Ministry of Higher Education and Scientific Research.

\section{REFERENCES}

[1] Zhang LP, Liu WZ, Guo WW, Bao J, Zhang XY, Liu JN, Wang DL, Meng FY, Liu ZX. (2016). Interface processing of amorphous-crystalline silicon heterojunction prior to the formation of amorphous-tonanocrystalline transition phase. IEEE Journal of Photovoltaics

$6(3)$. https://doi.org/10.1109/PVSC.2015.7356403

[2] Paviet-Salomon B, Tomasi A, Descoeudres A, Barraud L, Nicolay S, Despeisse M, Wolf SD, Ballif C. (2015). Back-contacted silicon hetero junction solar cells: optical-loss analysis and mitigation. IEEE Journal of Photovoltaics $5(5)$ :

$1293-1303$ https://doi.org/10.1109/JPHOTOV.2015.2438641

[3] Meng FY, Shi JH, Shen LL, Zhang LP, Liu JN, Liu YC, Yu J, Bao J, Liu ZX. (2017). Characterization of transparent conductive oxide films and their effect on amorphous/crystalline silicon heterojunction solar cells. Japanese Journal of Applied Physics 56: 04CS09. https://doi.org/10.7567/JJAP. 56.04C S09
[4] Si FT, Isabella O, Zeman M. (2017). Too many junctions? A case study of multijunction thin-film silicon solar cells. Advanced Sustainable Systems 1(10). https://doi.org/10.1002/adsu.201700077

[5] Masafumi Y. (2003). III-V compound multi-junction solar cells: Present and future. Solar Energy Materials \& Solar Cells 75(1-2): 261-269. https://doi.org/10.1016/S0927-0248(02)00168-X

[6] Ganouni R, Talbi M, Ezzaouia H. (2017). Comparative study of experimental and theoretical model of highlyefficient GaInP/Si tandem solar cells. Journal of Semi Conductor Technology and Science 17(6): 878-885. https://doi.org/10.5573/JSTS.2017.17.6.878

[7] www.ac-clermont.fr/disciplines/index.php?id=5219

\section{NOMENCLATURE}

$\begin{array}{ll}\text { PVG } & \text { Photovoltaic Generator } \\ \text { a-Si:H/c-Si } & \text { Amorphous/crystalline silicon } \\ \mathrm{I}-\mathrm{V} & \text { Current vs Voltage Characteristic } \\ \mathrm{P}-\mathrm{V} & \text { Power vs Voltage Characteristic } \\ \mathrm{TCO} & \text { Transparent, Conductive layer } \\ \mathrm{T}_{i} \mathrm{O}_{2} & \text { Dioxyde de titane } \\ \mathrm{Al}_{2} \mathrm{O}_{3} & \text { Alumine } \\ \mathrm{Si} & \text { Silicon } \\ \mathrm{SHJ} & \text { Silicon Hetero-Junction }\end{array}$

